\title{
The Distribution Process of the Housing Stimulant Grants Program (BSPS) during COVID-19 Pandemic Situation in Muncan Village, Karangasem Regency
}

\author{
Ni Luh Putu Juniartini ${ }^{1}$, I Wayan Juniartha ${ }^{2}$, I Nyoman Anom Fajaraditya Setiawan ${ }^{3}$ \\ ${ }^{1}$ Tenaga Fasilitator Lapangan (TFL) Satuan Kerja Non Vertikal Tertentu (SNVT), Kementerian \\ Pekerjaan Umum dan Perumahan Rakyat (PUPR). \\ ${ }^{2}$ Program Studi Sastra Inggris, Fakultas Bahasa Asing, Universitas Mahasaraswati Denpasar. \\ ${ }^{3}$ STMIK STIKOM Indonesia \\ Email: ${ }^{1}$ uniraditya@gmail.com, ${ }^{2} \mathrm{r}$ juniartha@yahoo.com, \\ 3anomkojar@stiki-indonesia.ac.id
}

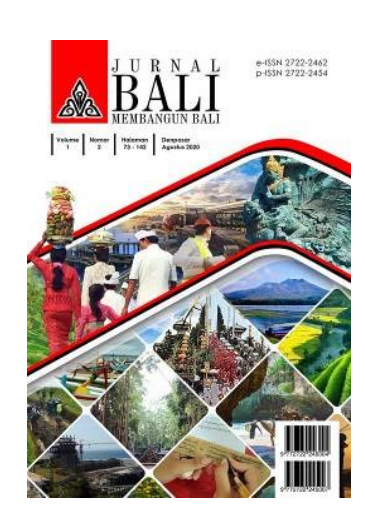

Article History

Received on 15 April 2020

Revised on 5 May 2020

Accepted on 16 May 2020

\section{Abstrak}

Tujuan: Tujuan tulisan ini adalah mengetahui keberadaan BSPS yang merupakan program pemerintah melalui PUPR dan ulasan berfokus di Desa Muncan Kabupaten Karangasem sebagai salah satu wilayah penerima bantuan. Program mengikuti keputusan, arahan, aturan serta prosedur yang telah ditetapkan pemerintah Provinsi Bali.

Metode penelitian: Data dianalisis untuk memisahkan kriteria yang terkait dengan masalah dan solusi, dan juga penyelesaian berdasarkan prosedur serta secara purposive menentukan informan berdasarkan kriteria dan pertimbangan tertentu.

Temuan: Kendala bertambah rumit dengan kemunculan pandemi Covid-19 yang berdampak pada berbagai lini secara global. Tindakan khusus perlu dilakukan terutama oleh TFL dengan masyarakat. Selain harus menjalankan prosedur dan aturan dalam penyaluran bantuan, tindakan preventif menyikapi berbagai kondisi lapangan perlu pula dipikirkan. Analisis menjadi dua kategori yakni kondisional kegiatan verifikasi BSPS agar tetap berjalan dan inisiatif menyikapi situasi krisis pandemi Covid-19 di lapangan.

Implikasi: Berbagai kendala yang dihadapi diharapkan menjadi suatu pertimbangan atau kajian untuk periode berikutnya, terutama dengan hal-hal yang tidak terprediksi dan bersifat force majeure beserta tim yang bertugas secara langsung di lapangan.

Kata kunci: program bantuan, rumah swadaya, COVID-19, pandemi, Muncan, Karangasem.

\section{Abstract}

Purpose: The purpose of this study is to know the existence of BSPS as a government program through PUPR and the review focuses on Muncan Village, Karangasem Regency, as one of the beneficiary areas. The program follows the decisions, directions, rules, and procedures established by the provincial government of Bali.

Research methods: The data are analyzed to separate criteria related to problems and solutions, and also solutions based on procedures and purposely determine informants based on specific criteria and considerations.

Findings: Constraints were complicated by the emergence of the Covid-19 pandemic, which has an impact on various lines globally. Particular action needs to be taken primarily by TFL with the community. In addition to having to carry out procedures and rules in the distribution of aid, preventive measures addressing various field conditions also need to be considered. The analysis is divided into two categories: conditional on BSPS verification activities to keep going and initiatives to address the Covid-19 pandemic crisis in the field.

Implications: The various obstacles faced are expected to become a consideration or study for the next period, especially with things that are unpredictable and are force majeure along with the team that is tasked directly in the field.

Keywords: aid programs, self-subsistence houses, COVID-19, pandemic, Muncan, Karangasem 


\section{INTRODUCTION}

Everyone has a dream to own a proper house since house is third basic needs in our life after food and clothes. House needs a various consideration of its eligibility as it considers some aspects, construction criteria, and comfortableness aspects as well as the security of the building. Those aspects closely related to the footing, building structure, and other important aspects that becomes the eligibility policy of the building. In Indonesia, the policy is taken from the decree that has been established by the Ministry of Public Works and Housing of Indonesia (Pekerjaan Umum dan Perumahan Rakyat/PUPR) and guidance from World Health Organization (WHO) about healthy house for people.

Based on the eligibility policy, PUPR then establishes a program that has a purpose in enhancing the eligibility of people's house in Indonesia called The Housing Stimulant Grants Program (Bantuan Stimulan Perumahan Swadaya/BSPS). In detail, the discussion section will be focused on the distribution in Muncan Village area, Karangasem regency, Bali. As a progressive program, BSPS begins its process directly on the location of distribution, as the stages are done directly onto the target area based on the location distributed by PUPR provincial official. With direct verification, then the Facilitator team factually acknowledges the condition of the recipient area before it reaches the decision stage. Beside, this stage became an important consideration to a decision as well as criteria and terms. The interaction to the recipient becomes an obligatory activity. It also requires intensive communication with the officials of acceptor's area in order to learn about its culture.

The early activity of this program has been conducted before the year of 2020 and it includes the early verification to the acceptor based on the recommendation from each area. Unpredictably, the COVID-19 pandemic has brought a big issue in every aspect, particularly on the further process of BSPS program. This pandemic force people follow the procedure of social distancing. It is an effort to cut the spreading of the virus. Furthermore, this issue is becoming more serious that the process of BSPS distribution needs a direct interaction to the people with different level of education, ability, and understanding. The dilemma between obligation and risk becomes a serious consideration, especially for the Facilitator Team (Tim Fasilitator Lapangan/TFL) who is working during this pandemic that changes the plan that had been set. For that, the preventive action from each party is needed, especially Facilitator Team (Tim Fasilitator Lapangan/TFL) in responding this force majeure.

Next discussion focuses on the BSPS formal procedures and also the social situation of people in Muncan village through this program. Moreover, the discussion 
also talkes about the distribution during the pandemic. Besides, the action conducted by Muncan village people in setting up the strategies in conducting the meeting related to BSPS as it is instructed needed to be discussed as well. By discussing all aspects mentioned above, it is known that every action conducted by parties, facilitator team and people of Muncan village is not violating the terms and does not causing loss. At last, this article takes role as the information extension domestically and internationally informing that in facing the era of pandemic crisis, the government of Indonesia is still continuing home improvement for lower class citizen through BSPS PUPR program.

\section{LITERATURE REVIEW AND METHOD \\ Livable Parameter}

The Indonesian Constitution article 1 of 2011 is becoming the reference of the criteria whether the house is livable or not. It states that a house is a building that is functioning as a livable living space; an instrument for family educational purposes that reflects the value of its occupant holds (UU RI No.1 tahun 2011). Meanwhile, WHO (2001) states that a house is a physical structure or building that has a purpose to give a shelter, where the environment is beneficial for physical, mental, and also social state for personal and family health (2001). The short definition about house from two references above can be assumed that a house is the most important part in life physically and comfortably especially when it is related to its occupant's healthiness and safety. It is emphasized by the Indonesian Constitution article 4 of 1992 about housing and resident. It states that a housing is the lines of houses which functions as a residence or occupancy equipped with related facilities and infrastructure (UU RI No.4 Tahun 1992).

Other reference states that a house is a place functions as a shelter from natural phenomena (Rain and sun strike) and as a place to rest after everyday activities (Suharmadi, 1985). It means that the process in building a house needs to consider its endurance from the disruption of natural disaster and related phenomena without putting aside the function as a place for daily activities. It is also related closely to the next references which states about the space adequacy for its occupants in conducting all activities and to avoid all factors that threatening the health of the occupants (Hindarto, 2007).

Those all references stated above can be assumed in a statement that an unlivable house is a residence or a shelter that does not follow the criteria, technically or non-technically, that related with space, function, water sources, clear water access, and bathroom. Other things includes non-permanent material, lack of ventilation, and also the buildings location which located too closed one to another (Juniartini, 2019). 
Those things mentioned above indicates the inability of the management in fulfilling the appropriateness comfortable aspect which results in other criteria.

One of the livable parameter refers to the statement of the Housing Finance Directorate General in the Ministry of Public Work and Housing of Indonesia (PUPR) stated that the width of the buildings minimum $9 \mathrm{~m}^{2} /$ person is related to the health of the occupant. Besides, the building has to meet structure component parameters, roof, floor, wall and its sanitation, temperature, lighting, and clean water. In general, the criteria explained above is shown in figure 1 and 2 that is referred from the Ministry of (PUPR) (Juniartini, 2019).

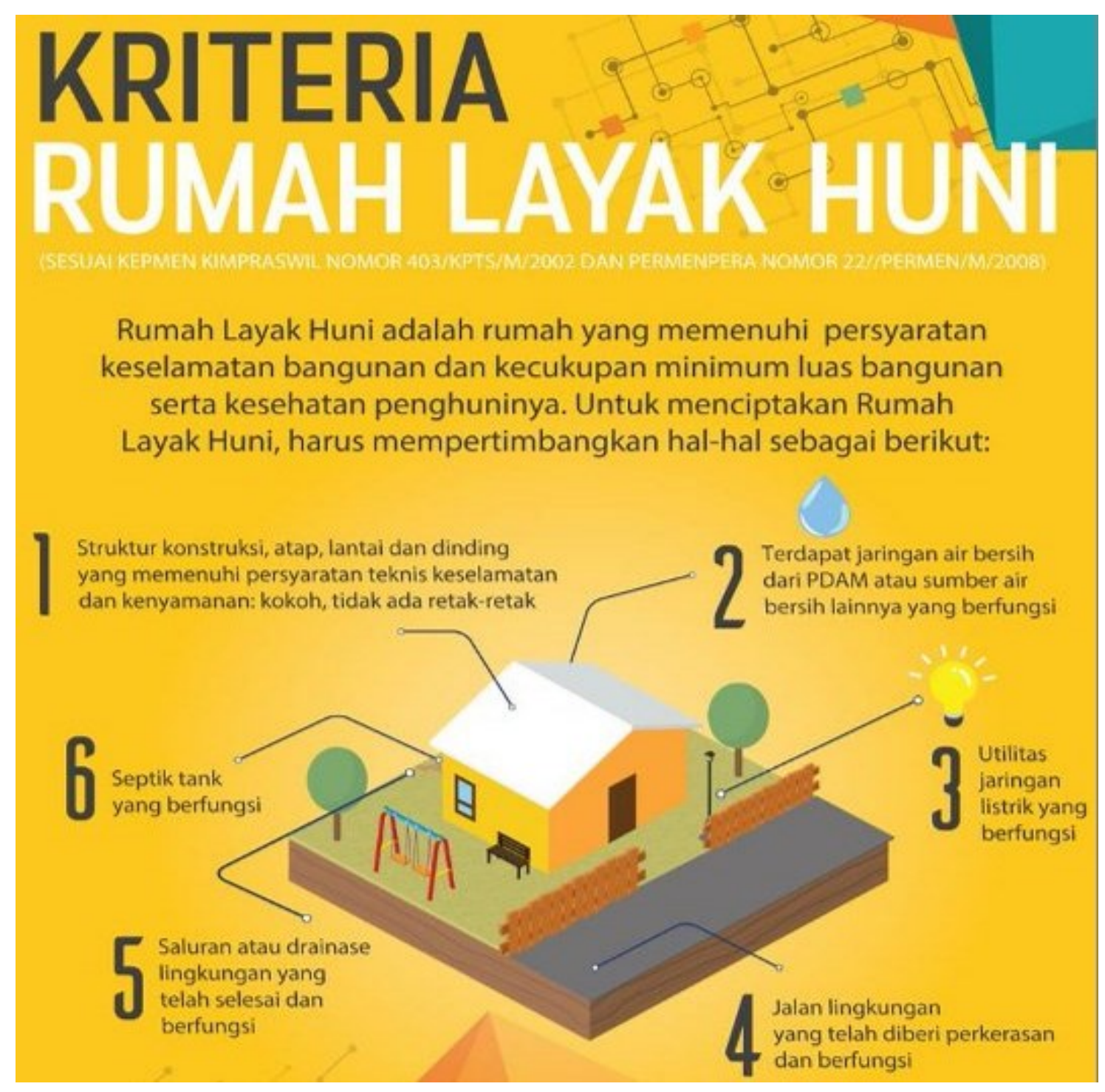

Figure 1: The infografic of livable house. Source: The Ministry of PUPR 


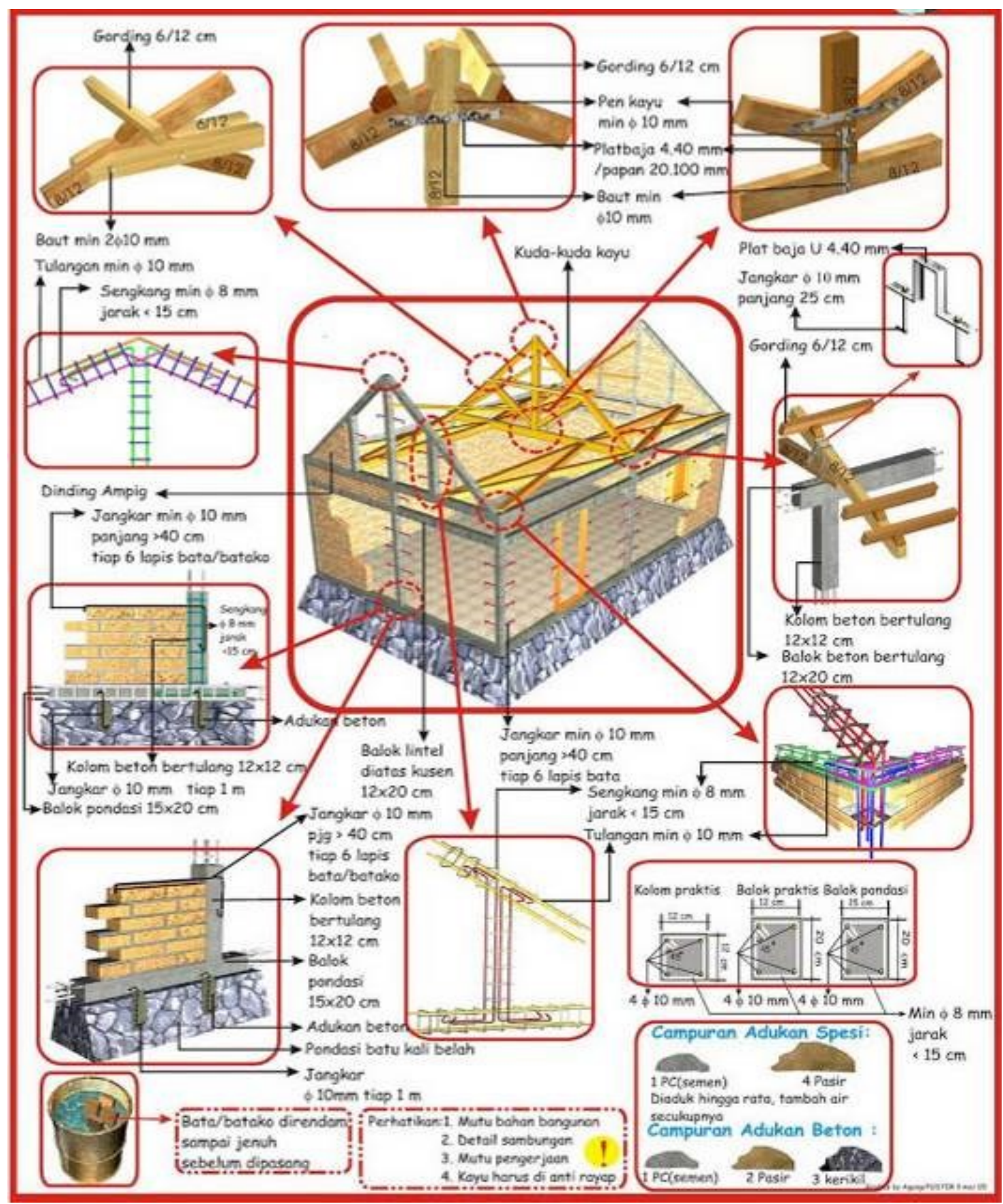

Figure 2: The minimum criteria of earthquake building with reinforced concrete

\section{BSPS Distribution Mechanism}

The data collection is done by comparing all proses of distribution in the area. The collected data then analyzed to separate the criteria related with the problems and solution, and also the completion based on the procedures. The method used in collecting the data was purposive sampling, that was determining the informants based on particular criteria and consideration (Sugiono, 2011) Based on the criteria, the data was taken from the people who are domiciled in Muncan Village, lived in the only house with improper condition, and the income is under the regional minimum wage 
that is IDR 2,355,054 in 2019 (https://bali.idntimes.com). The following criteria is that the informant has never granted any housing program aid whatsoever and agree on the action to contribute in a group who consists of the acceptor of the grant (Kelompok Penerima Bantuan/KPB). Muncan Village is a part of the areas in Selat district that has the population around 8,327 people based on (https://karangasemkab.bps.go.id/) in 2019 which spread out in 8 villages with 100 houses of CPB or the candidate of aids acceptor.

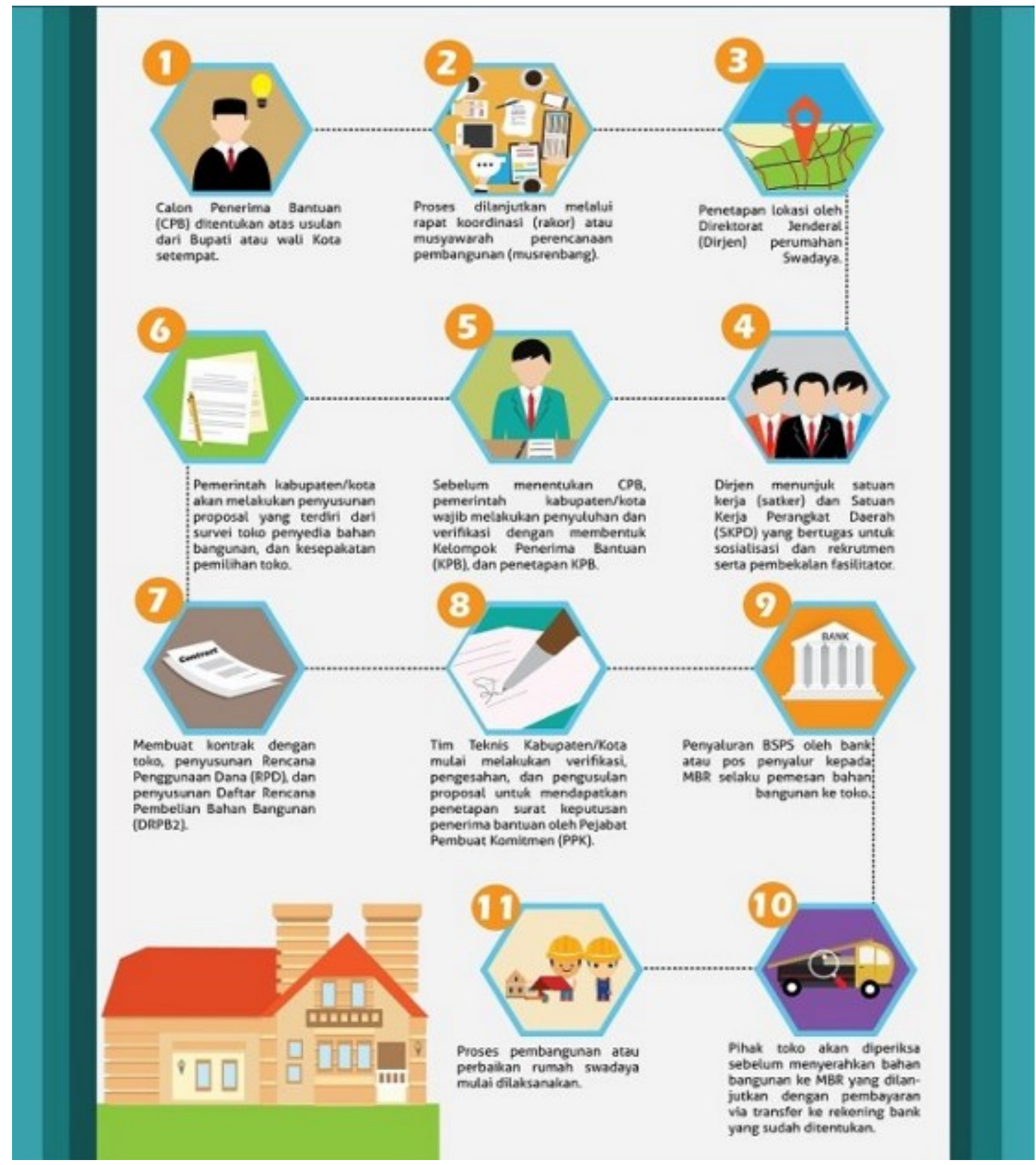

Figure 3: The infographic of the mechanism of BSPS grant 
The data was determined through the mechanism that occurred in BSPS which was collected in collective way from Muncan village, Selat district, Karangasem regency as what was explained below (figure 3):

1) The candidate of aids acceptor (Calon Penerima Bantuan/CPB) is determined by regent suggestion through the recommendation of the village officials.

2) The decision is followed up by doing the coordination meeting of development planning called MusRemBang (Musyawarah Perencanaan Pembangunan/Development Planning Conference).

3) The location is chosen by The Directorate General of Housing

4) The indication of SKPD (Satuan Kerja Perangkat Daerah/ Regional Apparatus Work Unit) who are chosen to do socialization, recruitment and help as the provisioning facilitator

5) The local government has to do the elucidation and verification by assigning TFL, then creating KPB as well as validation

6) The local government needs to make a proposal and survey the material suppliers as well as create a dealing

7) Making a contract with material suppliers, arranging the total fund expenses and the plan of material purchasing

8) Technical team of the regency verifies, validates, and proposes the decision letter that has been made by Commitment Establisher

9) Contributing the fund from the bank or through the citizen contribution post to citizen with minimum wages

10) The transaction is done via transfer among the bank accounts that have been determined

The development process is done based on the determination.

\section{The Issue and Solution of the Previous Contribution of BSPS in Tusan Village}

When the verification of the first step a year before the contribution is done, TFL learns about the situation in the chosen area (the coordination area is different in each TFL all around Bali), however the topic is focused in one area, which is Muncan Village. It happens because the contribution data of BSPS are mostly collected by people from Muncan Village. The analysis of situation belongs to the activity of BSPS from the previous period which is Tusan Village, Banjarangkan District, Klungkung Regency that has been published in 2019. That situation becomes the parameter of the experience in doing BSPS in 2020 in acknowledging the social situation and culture in Muncan Village area. 
The issue and initiative solution previously occured from Juniartini (2019) to BSPS in Tusan Village are:

1) Social issue: the relation between each person and the environment of the village that creates an unwillingness in working together with outsider even it is needed Solution: motivating and supporting the workers to collaborate based on their specialty

2) Education issue: the building process is conducted based on experience with no formal education but is only rely on experience which not appropriate to the rule.

Solution: supervising continuously to make the process runs properly regarding to the proposal and the formal regulation

3) Situation issue: the issue of scheduled process which is influenced by the custom and local religious activity that results into the delaying of the process.

Solution: The issue is anticipated by taking the advantage of the free time, as an instance by educating the work management cooperatively.

According to the discussion, the experience of the previous situation becomes the important component in perceiving the different indication in different area which is Muncan Village. However, it is creates the possibility if the previous issues re-emerged.

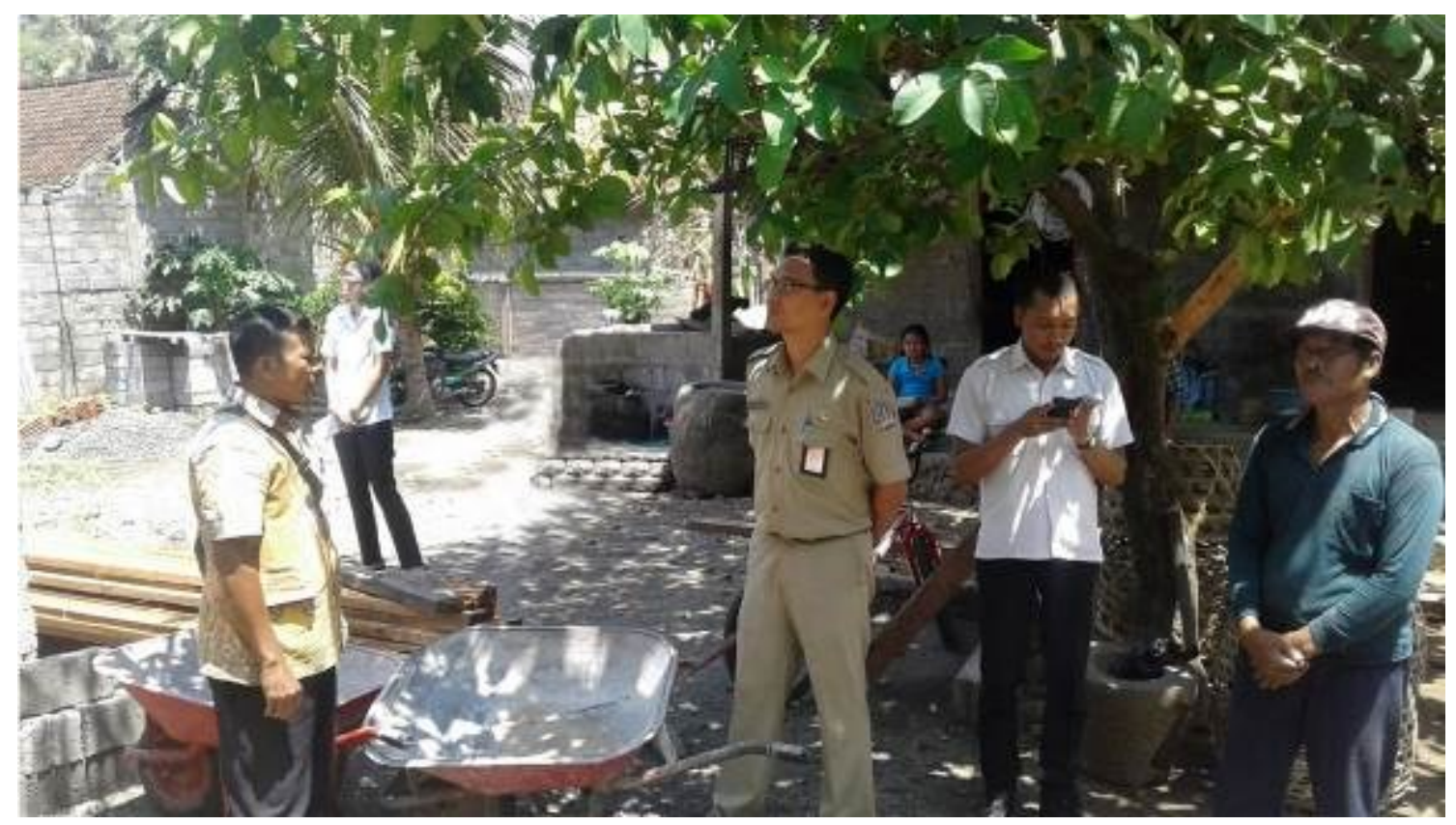

Figure 4: The Field observation continually done by PPK Rumah Swadaya, Putu Harry Krisnawan, ST., M.Si. located in Klungkung regency (2019)

\section{About COVID-19 Pandemic}

As the new issue occurs, the situation is becoming complicated by the spreading of COVID-19 that totally changes the situation and it forces TFL to re- 
arrange the working plan in the field. This thing is becoming more difficult since there is a limitation in doing activity as what government has declared in order to prevent the spreading of the disease, meanwhile the duration of the program runs as what it was planned before without any changes. The preventive way is needed in this unpredictable situation, and the self-anticipation in the field.

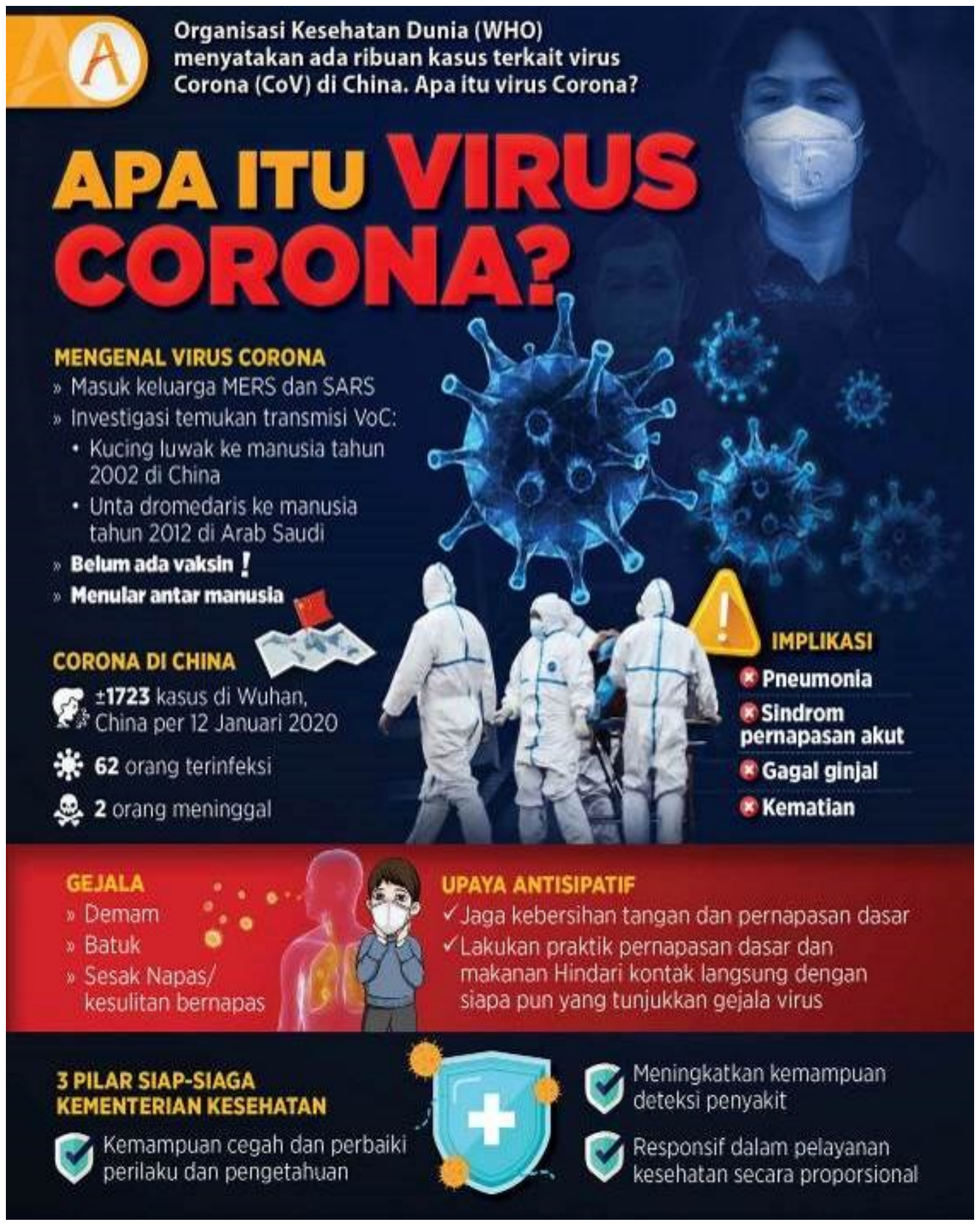

Figure 5: The infographic of Corona. Source: akurat.co. January 2020 
COVID-19 is a virus that is commonly called as corona virus or SARS-CoV-2. This virus has become the global pandemic and it has been spread out in more than 190 countries the world included Indonesia (https://www.kompas.com/). Then, that global disease forces any anticipative actions to push the graphic of the spreading and infecting as what has happened massively. The ways in anticipating the infection of the disease are social distancing, isolation, quarantine, lockdown, flattening the curve, and supervising and controlling the patient (https://www.alodokter.com/).

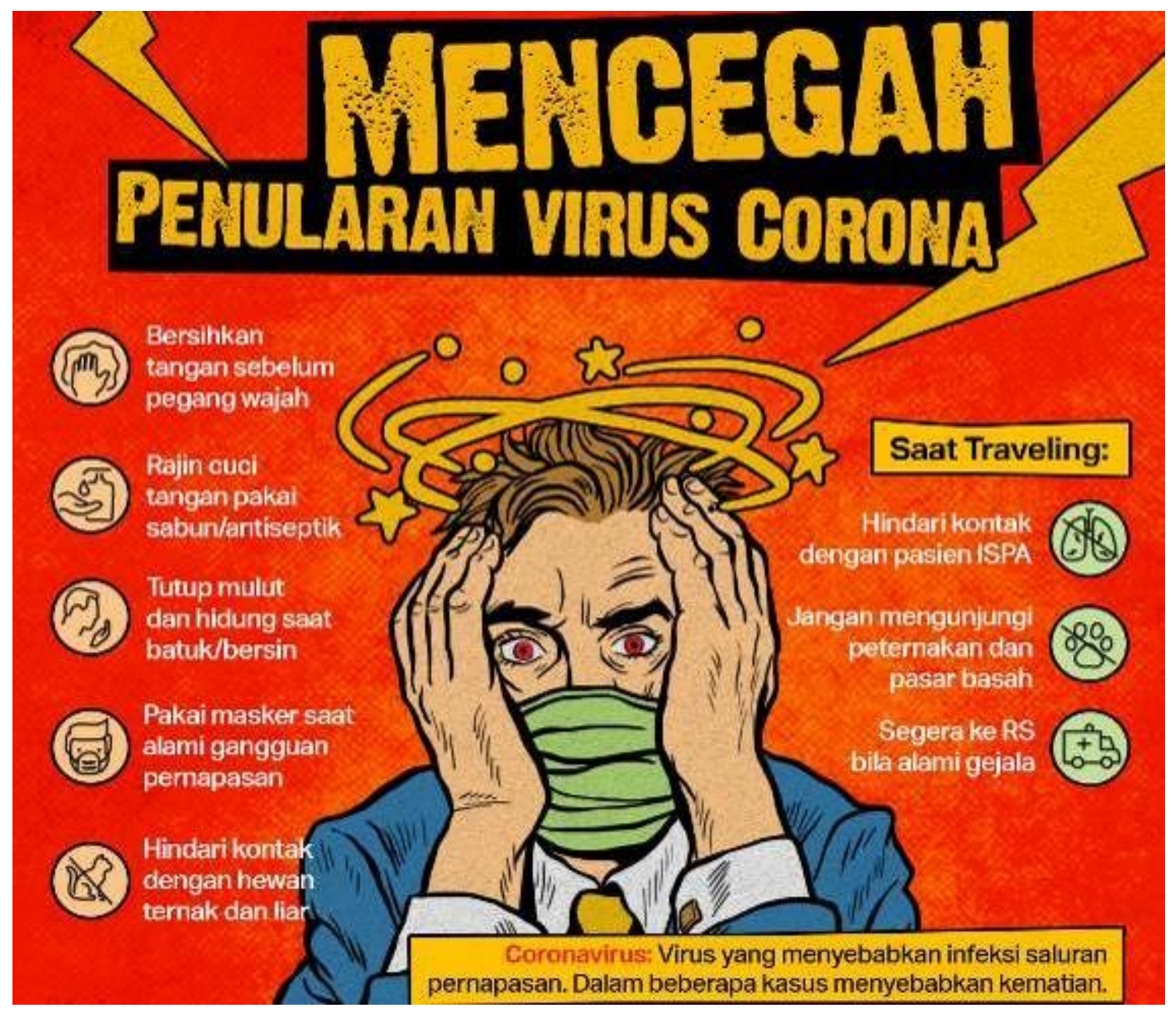

Figure 6: The infographic of announcement how to prevent the spreading of Corona. Source: kumparan

The occurrence of COVID-19 in Indonesia and the exertion in pushing the spreading of the disease force the government and its component to do preventive action to face the pandemic and also reminding the people to be able in cutting its spreading. This makes any fluctuations that generally influence the daily life of the people. The recommendation in leaving the daily life, avoiding the crowd, blocking the access, working from home and so on are the things that need to be considered. 
(https://www.kompasiana.com/). Regarding to the recommendation of the government and BSPS, it may have the impact in the process of verification in the field as well as the risk that may be faced by TFL

\section{DISCUSSION}

In the introduction it has been explained that there are two problems need to be analyzed. First, early process of the BSPS program related to the data and the second, the awareness onto the unpredictable COVID-19 pandemic. The discussion is limited into the condition in the field to the fourth month in 2020 (conditioned article publication and pandemic), since the process is limited by the unstable situation and related with government policy in preventing the pandemic by limiting every form of activities. Based on the explanation above, the data collection which was analyzed qualitatively is limited to the activities done in November 2019 to April 2020 and is described factually.

\section{The Factual Condition of Muncan Village (Procedure T-1)}

Procedure $T-1$ is the surveying process which related to surveying the data of field verification onto Aid Program Candidates (CPB) conducted by Facilitator Team who takes role as the verification officials before they are entering the year of realization of 2020 . The time span of the administrative proposal preparation to the execution is stated from November to December 2019. In term of mechanism, the process that has been conducted is referring onto point 1 to point 6 of the BSPS mechanism scheme explained in subchapter 2.2. The job description is stated in the decree SNVT No.111/KPTS/SNVT-PnP.BALI/2020 and one of Facilitator Team is placed in Muncan Village sub district BSPS, Karangasem regency.

Generally, the field condition is referring into three points, they are: social condition, educational condition, and situational condition which is based on recent socio-cultural condition. It can be described that those conditions will emerge various basic issues especially when the verification process in proposed location is conducted. The issues that emerged apart from the system and procedures based on the SOP BSPS 2019 (for the verification procedure T-1), are:

1) Social issue

- There are different political point of views in several groups from the election of village head.

- There are family disputes within one house that makes the supervision session is becoming tough. 
- The administrative status of the society, the unmarried status makes they have no opportunity to be listed in the list of acceptor meanwhile they are qualified in other criteria.

- The awareness to sign up in order to get their administrative identity is lacking.

2) Educational issue

- The general understanding stated that BSPS is a cash and carry distribution to the acceptor

- The awareness of aid acceptors in following the process that need to be obeyed is lack

- The indication that some people are suspected doing the intervention by complicating the administration and bureaucracy which officially stated in the SOP.

3) Situational issue

- The facility access and infrastructure is lacking that is result into the implementation of the program takes longer time than it supposed to be (for example: some locations where the aid acceptor lived have to be visited by walking several hours to get into)

- The sloppy and rocky road that need to be gone through to find the acceptor's location which are quite far one to another.

Here are some documentation collected based on the fact and also the condition of the acceptor's house in Muncan Village.

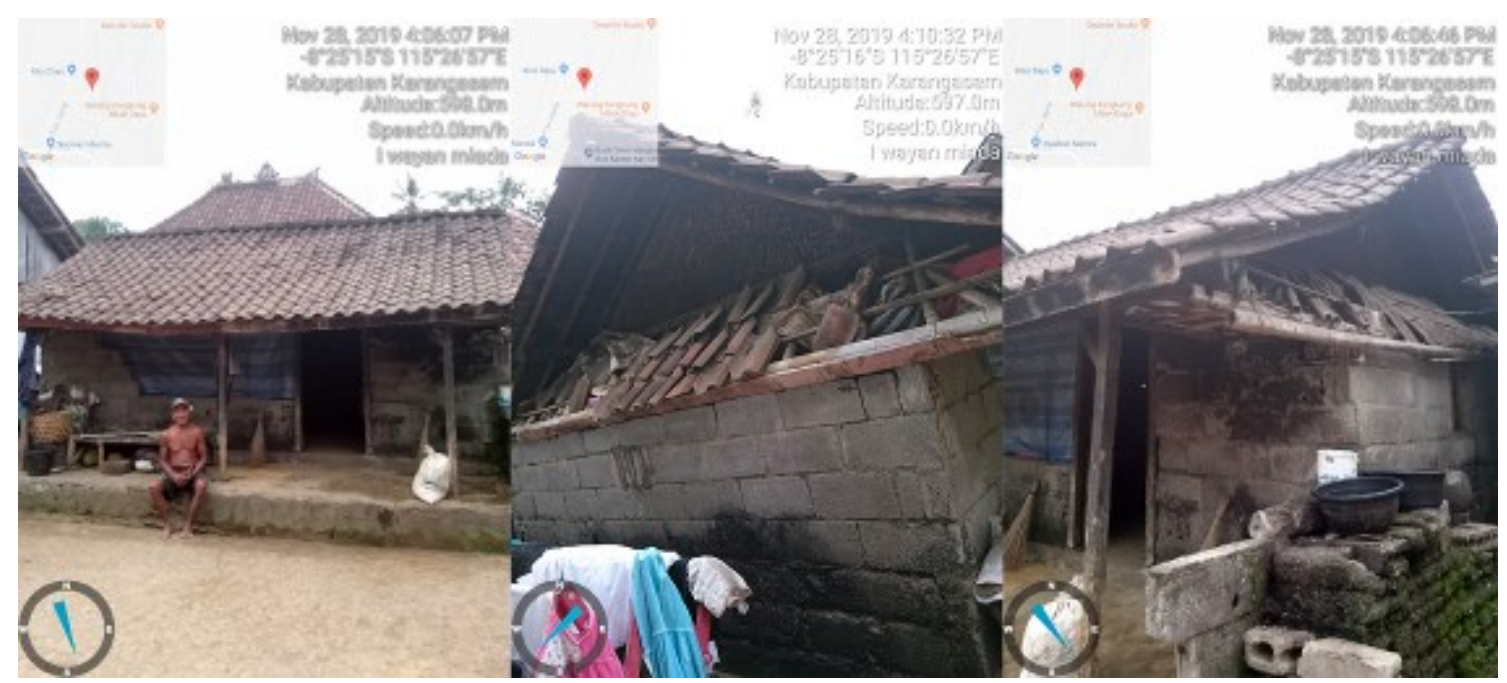

Figure 7: The condition of I Wayan Miada's house (one of the aid acceptor in Muncan Village) 


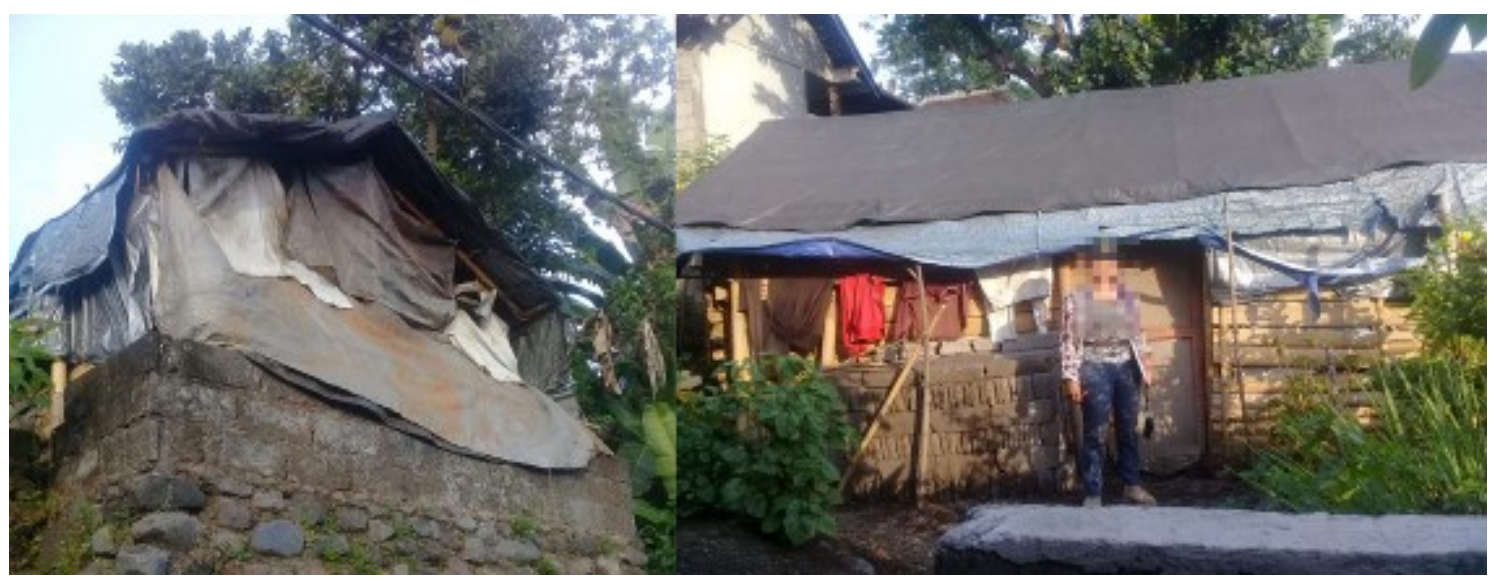

Figure 8: The condition of I Ketut Widya's house (one of the aid acceptor in Muncan Village)

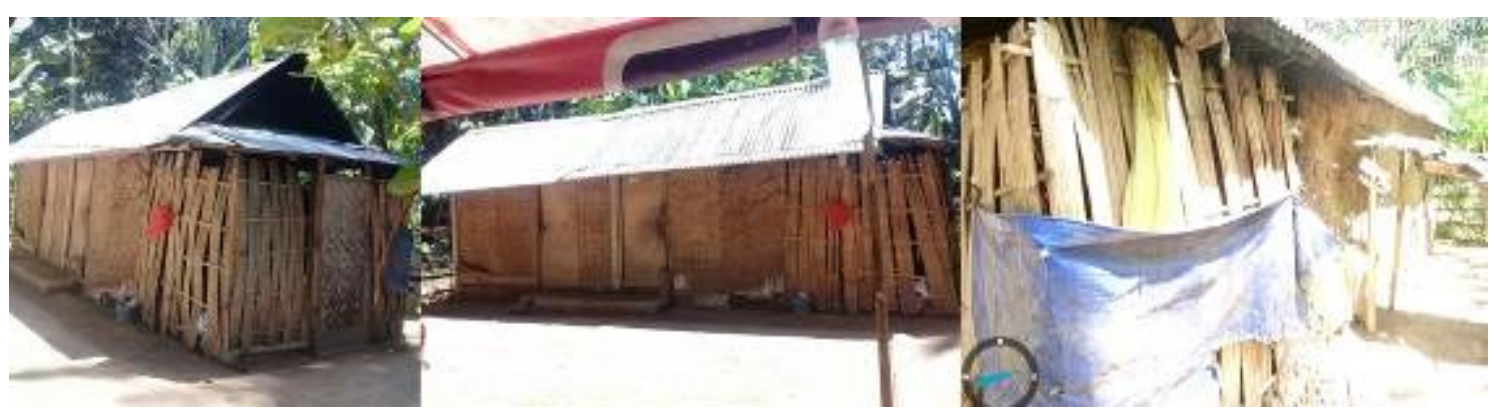

Figure 9: The condition of I Wayan Rena's house (one of the aid acceptor in Muncan Village)

\section{The Anticipation into Covid-19 Pandemic (ongoing to further process)}

The spreading of COVID-19 since the early of 2020 leads into a global disaster and forces the citizen of the world to be more aware in facing the situation and also to follow the effort prevent the spreading in every country. In Indonesia, COVID-16 has become a pandemic that change habits of Indonesian people who are like to work together with the proverb "Strength in number, Divide we fall". Apart from affecting the life philosophy, it also has a big impact over the economical aspect and strategic lines especially to this BSPS program.

Facing the recent condition, the implementation of BSPS takes the reference of the legal basis established by The Ministry of Public Work and Housing of Indonesia (PUPR), Directorate General of Housing, The Directorate of Self-Subsistent Housing, they are:

1) Indonesian Republic Constitution article 1 of 2011 about Housing and residential area

2) The decree of President article 11 of 2020 about the establishment of citizen emergency state over the Corona Virus Disease (COVID-19) 
3) The decree of Minister of Administrative and Bureaucratic Reform article 35 of 2012 about the Guidance of Government Administration's Standard Operational Procedure establishment

4) The decree of the Minister of Public Work and Housing of Indonesia article 03/PRT/M/2019 about organization and job description in the Ministry of Public Work and Housing of Indonesia

5) The decree of Minister of Public Work and Housing of Indonesia article 07/PRT/M/2018 about the Stimulant Program of Self-subsistent Housing

6) The decree of the Minister of Health article 9 of 2020 about the social distancing guidance and the Accelerated Preventive Action onto Corona Virus Disease (COVID-19)

7) The instruction of the Minister of Public Work and Housing of Indonesia Article 02/IN/M/2020 about the Accelerative Prevention onto Corona Virus Disease (COVID-19) in the Construction Services establishment

8) A Circular of Director General of Housing article 3 of 2020 about the Operating Procedure of Construction Working on Directorate Technical in Directorate General of Housing's environment during the Pandemic of COVID-19

9) The Prevention Protocol on COVID-19 in Construction Project of Construction Directorate General

Based on the legal basis mentioned above, it explains things related to the qualification of implementation, procedures, tools, warnings, notification and data collection. It is explained in detail and also shows the technical instruction in the implementation of The Housing Stimulant Grants Program (BSPS) during the pandemic COVID-19 that has to be followed by all citizens who involved. The legal basis is also takes role as reference and consideration in the working process and also becomes the technical guidance for those who are related, especially the Facilitator Team. This security protocol is established as a preventive deed during the Pandemic COVID-19 and as basic information to educate the community in understanding the preventive strategy in each area. 


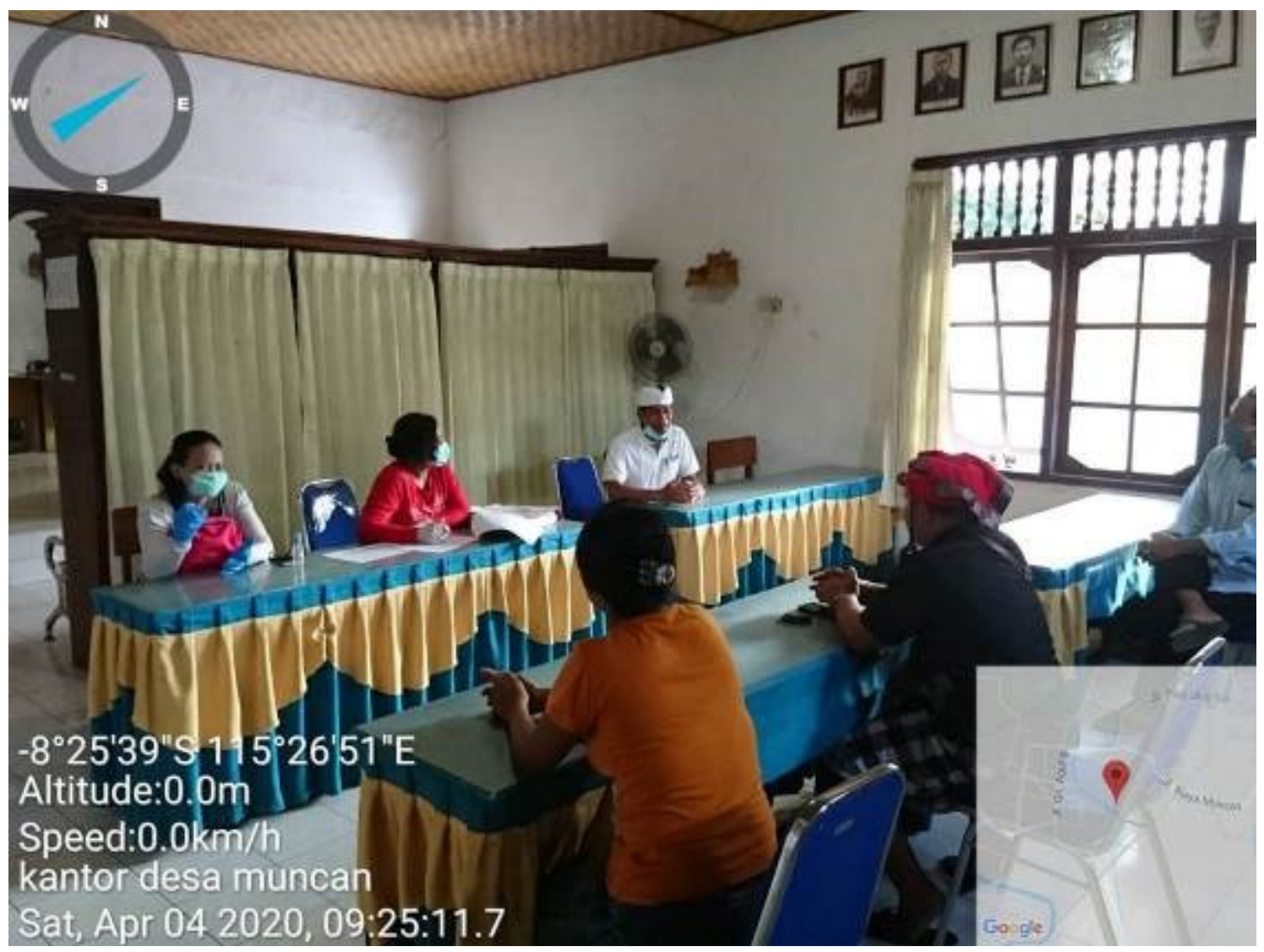

Figure 10: The meeting situation of TFL, village officials, security, and society talking about the prevention protocol of COVID-19 by social distancing, limiting the presence, using mask. TFL of Muncan village prepares medical devices by self-inisiative

\section{The Analysis of Contribution Process of BSPS along the Corona Disease (COVID-19)}

The analysis is categorized into two things; they are the situation of Muncan Village from the implementation of T-1 and the anticipative action to COVID-19 that relates to the realization of BSPS in the field. The analysis of action that should be done in implementing BSPS and facing the unpredictable situation are:

1) Field Analysis

- Regarding to the social issue in behaving the situation and condition of the field, TFL, and competent apparatus (management structure in each area based on the custom (unofficial) and official duty, traditional security officials, police, Indonesian National Armed Forces, and the local offials) need to work together in planning, realizing the proper action, and preventive and persuasive solution during the situation, thus the process of BSPS runs as planned.

- Related to education issue, TFL and the BSPS socialization team need to give an understanding to the candidate of aids acceptor and the other partners about all of the things that relate to the rights, obligations, and the risks. The agreement is also 
needed which refers to the self-initiative of aids acceptor and the other colleagues as well as the declaration of official statement that has a legal force. The other things is the emphasizing that the process and the duty procedurally done by field team cannot be intervened by other people and it is protected by the law.

- Related with the situation issue, the coordination and assessment in each area is needed, especially in Muncan Village which talks about the duration and the schedule which one of them is based on the consideration of the field situation. This thing, for sure, relates to the next development and administration process (after T-1) about duration, distribution, and implementation process.

\section{2) Pandemic Anticipation Analysis}

There are three things that relate each other and they should be running well in the technical implementation as well as facing the global disease, they are::

- The cooperation among province, regency government, and BSPS team is related to the implementation of the law and facilitation to the field team who directly facing the aids acceptors. These things are regarding to the standard operational procedure of occupational safety and self-protection (material and non-material) of particular situation in the field during COVID-19.

- The internal cooperation among BSPS team particularly those who relate to the information and communication in each area with its structure especially coordinating the issue faced in the field (the changing condition because of the pandemic).

- The cooperation between BSPS team and the society (village officials, security, aids acceptor, colleague, and others who involved) in following the standard operational procedure, the ethics, and respecting the integrity during the process of BSPS.

\section{CONCLUSION}

There are several points that become the conclusion of the discussions, as they are explained in detail in the sub chapters. These are not only obtained to the field team, but also everyone especially the general BSPS team. Furthermore, it can be concluded as follows:

- $\quad$ Field Facilitator Team (TFL) and Facilitation Coordinator (KorFas) as the frontliner of this program need to do proper communication (apart from the explanation in the analysis), learn, and understand about the situation of each area. 
- TFL and KorFas need to understand the issue and they have to make solutions and also doing coordination with their supervisor in having a solution and unpredictable issues (in the pandemic of COVID-19) beside the general issue.

- The field team must comprehend the coordinated prevention action over issues which include their duty in this pandemic and having self-initiation in every emergency situation of corona virus especially when the interaction to the society happens.

- $\quad$ Regarding to COVID-19 pandemic, TFL has the additional responsibility to educate the society in each area about this pandemic and preventing the infection, thus the next process of BSPS standard operational procedure would be running well in the particular situation.

As the suggestion, there are few things that need to be studied about the force majeure (COVID-19 pandemic situation) which relates to the contribution procedures, the consideration of the situation, administration, and the other components for the particular situation that could not be predicted and may ruin the contribution process. The other suggestion is that the communication process needs to be considered with the aids acceptor since it is less possible if the communication is done through video call as the operation process will be intruded. The issues will be happen on how the related software and hardware is operated that an additional fund is needed and the limitation of acceptor's knowledge.

\section{REFERENCES}

Badan Pusat Statistik. 2017. Kecamatan Selat dalam Angka 2017. Badan Pusat Statistik Kabupaten Karangasem

Badan Standar Nasional Indonesia. 1990. SNI 03-1979-1990 tentang Matra Ruang. Badan Standardisasi Nasional: Jakarta.

Dipohusodo, Istimawan.1996. Manajemen Proyek \& Konstruksi. Kanisius: Jogjakarta.

Direktorat Rumah Swadaya. 2020. Standar Operasional Prosedur Pelaksanaan Bantuan Stimulan Perumahan Swadaya Selama Masa Pandemik COVID-19. Direktorat Jenderal Perumahan, Kementerian Pekerjaan Umum dan Perumahan Rakyat.

Ermali, Ayu Afria Ulita. 2019. Daftar UMK Kabupaten-Kota di Provinsi Bali Terbaru 2020. [online] (Updated 29 November 2019) URL: https://bali.idntimes.com/life/career/ayu-afria-ulita-ermalia/daftar-umkkabupaten-kota-provinsi-bali/full [Dlakses pada 10 Maret 2020] Hindarto, P. 2007. “Inspirasi Rumah Sehat di Perkotaan”. Andi: Yogyakarta. 
Juniartini, Ni Luh Putu. 2019. Tinjauan Penyaluran Dana BSPS di Desa Tusan, Kecamatan Banjarangkan, Kabupaten Klungkung. Bali Membangun Bali, 2 (3), pp. 161-172.

Komisi WHO Mengenai Kesehatan dan Lingkungan. 2001. Planet Kita Kesehatan Kita. Kusnanto H (Editor). Yogyakarta : Gajah Mada University Press, p. 279.

Nadhira, Andi Marsa. 2020. Beragam Istilah Terkait Virus Corona dan COVID-19. [online] (Updated 27 Maret 2020) URL: https://www.alodokter.com/beragamistilah-terkait-virus-corona-dan-covid-19 [Dlakses pada 10 Maret 2020]

Peraturan Menteri Pekerjaan Umum Dan Perumahan Rakyat Republik Indonesia Nomor 07/PRT/M/2018 tentang Bantuan Stimulan Perumahan Swadaya.

Putri, Gloria Setyvani. 2020. Mengenal Gejala Virus Corona Baru Penyebab Covid-19. [online] (Updated 24 Maret 2020) URL: https://www.kompas.com/sains/read/2020/03/24/110100923/mengenal-gejalavirus-corona-baru-penyebab-covid-19 [Dlakses pada 10 Maret 2020]

Sugiyono. 2011. Metode Penelitian Kuantitatif Kualitatif dan R\&B, Alfabeta, Bandung.

Suharmadi. 1985. Perumahan Sehat, Proyek Pengembangan pendidikan tenaga Kesehatan Departemen Kesehatan RI. Jakarta.

Sutaryo; Kusdjono. 1984. Kamus Istilah Teknik Sipil. Depdikbud: Jakarta.

Undang-undang Republik Indonesia Nomor 1 Tahun 2011 Tentang Perumahan Dan Kawasan Permukiman.

Undang-undang Republik Indonesia Nomor 4 Tahun 1992 Tentang Perumahan Dan Permukiman. 